\title{
Problematic Internet Use, Emotional Problems and Quality of Life Among Adolescents
}

\author{
André Luiz Monezi Andrade' \\ Sônia Regina Fiorim Enumo ${ }^{1}$ \\ Maria Aparecida Zanetti Passos ${ }^{2}$ \\ Eliana Pereira Vellozo ${ }^{2}$ \\ Teresa Helena Schoen ${ }^{2}$ \\ Marco Antônio Kulik ${ }^{3}$ \\ Sheila Rejane Niskier ${ }^{2}$ \\ Maria Sylvia de Souza Vitalle ${ }^{2}$ \\ ${ }^{1}$ Pontifícia Universidade Católica, Campinas, São Paulo, Brasil \\ ${ }^{2}$ Universidade Federal de São Paulo, São Paulo, São Paulo, Brasil \\ ${ }^{3}$ Universidade de São Paulo, São Paulo, São Paulo, Brasil
}

\begin{abstract}
This study aimed to evaluate the prevalence of Problematic Internet Use (PIU) among adolescents $(N=466)$ and its possible association with emotional problems and quality of life. Students (Mage $=12.8$ years; $\mathrm{S} D=1.9)$ from five public schools in a city in the State of São Paulo participated in this study and completed four instruments: a sociodemographic questionnaire; Internet Addiction Test (IAT); Depression Anxiety Stress Scale (DASS-21) and Pediatric Quality of Life Inventory (PedsQL). No significant differences were detected about the frequency and intensity of symptoms of depression, anxiety, and stress compared to those who did not have problems with the use of the Internet. No differences were observed between the groups in respect of quality of life either. However, those individuals who felt that their internet use impaired their daily activities presented higher average IAT scores and higher levels of stress. These findings indicated that the perception of internet use was the main variable associated with emotional symptoms.
\end{abstract}

Keywords: Adolescent psychology, Internet (addiction), Mental disorders, Quality of life

\section{Uso Problemático de Internet, Problemas Emocionais e Qualidade de Vida entre Adolescentes}

\section{Resumo}

O objetivo deste trabalho foi avaliar a prevalência de Uso Problemático de Internet (UPI) entre adolescentes $(N=466)$ e sua possível associação com problemas emocionais e qualidade de vida. Estudantes (Midade $=12,8 ; D P=1,9)$ de cinco escolas públicas de um município do Estado de São Paulo participaram deste estudo e preencheram quatro instrumentos: Questionário sociodemográfico; Internet Addiction Test (IAT); Depression Anxiety Stress Scale (DASS -21) e Pediatric Quality of Life Inventory (PedsQL). Não se encontrou relação significante entre a frequência e intensidade dos sintomas de depressão, ansiedade e estresse em comparação com aqueles que não possuem problemas com o uso da internet. Em relação à qualidade de vida, também não foram observadas diferenças entre os grupos. Entretanto, aqueles que possuíam uma percepção de uso de internet prejudicial a suas atividades cotidianas apresentaram maior pontuação média do instrumento IAT e maiores níveis de estresse. Esses achados indicam que a percepção do uso do uso de internet foi a principal variável associada com sintomas emocionais. Palavras-chave: psicologia do adolescente, internet (dependência), distúrbios mentais, qualidade de vida

\section{Uso Problemático de Internet, Problemas Emocionales y Calidad de Vida entre Adolescentes}

\section{Resumen}

Este estudio tuvo como objetivo evaluar la prevalencia del Uso Problemático de Internet (UPI) entre adolescentes $(\mathrm{N}=466)$ y su posible asociación con problemas emocionales y calidad de vida. Los estudiantes (Midade $=12,8 ; D S=1,9$ ) de cinco escuelas públicas en una ciudad de la provincia de São Paulo participaron en este estudio y completaron cuatro instrumentos: un cuestionario sociodemográfico; Internet Addiction Test (IAT); Depression Anxiety Stress Scale (DASS-21) y Pediatric Quality of Life Inventory (PedsQL). No se detectaron diferencias significativas sobre la frecuencia y la intensidad de los síntomas de depresión, ansiedad y estrés en comparación con aquellos que no tuvieron problemas con el uso de Internet. Tampoco se observaron diferencias entre los grupos con respecto a la calidad de vida. Sin embargo, aquellas personas que sintieron que su uso de Internet perjudicaba sus actividades diarias presentaron escores promedios más altos de IAT y niveles más altos de estrés. Estos hallazgos indicaron que la percepción del uso de Internet fue la principal variable asociada a los síntomas emocionales. Palabras clave: Psicología del adolescente, Internet (adicción), Trastornos mentales, Calidad de vida. 
The use of digital media is an increasingly common global phenomenon, especially among young people, and is associated with technological advances and new dynamics in social interactions. Currently, it is estimated that more than four billion people use the Internet, with mobile devices being the primary means of access, with a penetration of $58.7 \%$ of the global population (IWS, 2020).

In Brazil, almost $70 \%$ of households have access to the Internet, and $33 \%$ of the population use it exclusively through mobile devices, according to the Brazilian Institute of Geography and Statistics (IBGE, 2018). In this report, the main uses of the Internet were to be the exchange of text or voice messages $(90 \%)$ and watching television and movies (76\%), mainly by using mobile devices. Besides, Brazil is ranked third in regardless the amount of time individuals spend online (on mobile devices or computer), with a daily average of 9.1 hours, three hours higher the global average (GWI, 2018).

A report by the Brazilian Internet Management Committee (BIMC, 2019) indicated that $86 \%$ of Brazilians aged between 9 and 17 had accessed the internet at least once in the previous three months, and 53\% regularly accessing the Internet exclusively through mobile devices. According to the Organization for Economic Co-operation and Development (OECD, 2017), Brazil is ranked second in respect of the amount of time spent online outside school hours, averaging 3.1 hours a day.

Internet is a valuable source for many types of use (Bedendo, Andrade, \& Noto, 2018), its use by children and adolescents can expose them to situations in which they are emotionally vulnerable, including cyberbullying, with $9 \%$ of Brazilian adolescents reporting having suffered some virtual discrimination, and $21 \%$ receiving some hate message aimed at specific groups of people (BIMC, 2019).

In addition to these risks previously described, problematic internet use (PIU) among adolescents has been increasing in a number of countries, particularly in Asia, with prevalence ranging from 12\% in South Korean (Heo, Oh, Subramanian, Kim, \& Kawachi, 2014) to $48 \%$ and $51 \%$ in Japanese and Filipino respectively (Mak et al., 2014). However, these findings are heterogeneous, and more recently Tateno et al., (2018), observed a prevalence of $21.6 \%$ in Japanese adolescents. In a study conducted in five European countries, almost $7 \%$ of adolescents $\left(M_{\text {age }}=14\right.$ years) showed PIU (Kaess et al., 2016).

In Brazil, figures about the prevalence of PIU are also heterogeneous. In one of the first Brazilian studies,
$62 \%$ of adolescents showed PIU (Della-Méa, Biffe, and Ferreira, 2016). In another study, of 15-24-year-old students, $11 \%$ were reported to have PIU (Terres-Trindad \& Mosmann, 2016). Recently, some authors detected that the prevalence of adolescents with PIU was $24 \%$ and 10\% among public and private school students, respectively (Cruz, Scatena, Andrade and De Micheli, 2018). Another study did not report any differences in the pattern of use between public and private school students, but the authors found that $21 \%$ of users had PIU (Machado et al., 2018).

The problematic internet use (PIU) is considered as an overuse of internet and has been associated with a number of physical and mental symptoms. Although PIU is not considered a mental disorder by either the ICD-10 or DSM-V, it types of internet behavioural addiction, among them, Internet-gaming disorder that was included in section III of DSM-V (APA, 2013). Besides, the symptoms of PIU are strongly associated with behavioural addictions, such as the excessive preoccupation about the internet use, need to increase the online time, lack of control use and neglect of social activities. The PIU has commonly been associated with externalizing problems such as aggression and opposition, and internalizing problems, notably higher levels of anxiety and depression (Lai et al., 2015), and has been associated with a lower quality of life (Chern \& Huang, 2018). Also, both the frequency and intensity of these symptoms tend to be inversely correlated to the age of the users, so that the younger the age, the greater the severity of the symptoms (Kuss et al., 2018). However, these findings also vary widely according to the sociodemographic characteristics of the population. In this sense, a 2-year prospective study conducted with Taiwanese adolescents, did not detect an association between depression and IA when depression was inserted in a multivariate logistic regression model (Ko, Yen, Chen, Yeh, \& Yen, 2009).

In Brazil, only one study has evaluated the relationships between PIU and quality of life in adolescents, in which the authors observed an association between the length of internet use and some quality of life domains (Cruz et al., 2018). Two studies, which considered symptoms of anxiety and depression, did not detect an association with PIU in adolescents (Della-Méa et al., 2016). In a study conducted with Brazilian medical students almost $90 \%$ reported negative effects of excessive internet use in their lives, mainly about studies $(68 \%)$, physical activity $(32 \%)$ and family relationships (21\%) (Moromizato, Ferreira, Souza, Leite, Macedo, \&

Psico-USF, Bragança Paulista, v. 26, n. 1, p. 41-51, jan./mar. 2021 
Pimentel, 2017). However, some authors identified an association between PIU and behavioral (aggression, attention deficit) and emotional (anxiety and depression) problems among adolescents (Machado et al., 2018). A common characteristic of all these studies is their small sample sizes, which limits more robust statistical inferences.

In this sense, new studies are necessary to better understand the association of emotional problems with PIU in Brazilian, particularly in adolescents. This study aimed to evaluate the prevalence PIU and perception of internet use among adolescents, and assess the associations of PIU with symptoms of anxiety, depression, stress, and quality of life. We hypothesized that; (i) the frequency of emotional problems would be higher among PIU adolescents; (ii) The quality of life's score would higher among those non PIU adolescents.

\section{Method}

\section{Characteristics of the study}

The present study is part of an epidemiological monitoring program of adolescents in public schools that are being implemented (pilot project) in a city in the State of São Paulo. In this program, several adolescent indicators are being monitored over some years, among them the use of digital media, quality of life, emotional aspects, nutrition, pubertal development, health-related conditions and behaviours, and education. These findings are combined with other pre-existing data about these students from the Health Education Program and Epidemiological Surveillance in Schoolchildren, Department of Education, a municipality in the state of São Paulo.

The program is a partnership between researchers, the local authority and the Education Department. The epidemiological monitoring project also includes some proposed interventions in different areas (psychology, dentistry, nutrition, etc.), focusing mainly on aspects related to health promotion in adolescents.

The schools were selected in the following way: we prioritized those institutions that mainly served low- and medium-income populations. Additionally, the inclusion criteria of the schools were: have a similar number of children enrolled between the ages of 9 years and 11 months and 17 years and 11 months; have sufficient human resources and facilities to take part; be easily accessible for researchers; have a number of children compatible with the number of people who made up the data collection team involved in the research. Thus, the local education department randomly selected five schools of each Region of the city to participate in this Program. Is important to highlight that these schools are a representative sample of all public schools in this city.

\section{Participants}

The sample comprised 466 students aged 9-17 years $\left(M_{\text {age }}=12.8, S D=1.9\right)$, attending five public schools in a city in the State of São Paulo who were participants in an epidemiological monitoring project. They should have at least one smartphone with internet access and 41 students were excluded from the sample because they did not have such a device.

\section{Instruments}

We used the following instruments:

A Socio-demographic questionnaire - with information on age; sex; education; income, and the pattern of smartphone use.

Internet Addiction Test (IAT) - which has 20 questions to assess patterns of internet use (maximum score of 100 points), with the risk of internet addiction increasing as the score increases. In this study, the participants were classified into two groups based on the score as proposed by Machado et al., (2018): (i) those with up to 50 points were considered Non-Problematic Internet Users (nPIU), and (ii) those with more than 50 points were considered Problematic Internet Users (PIU). When comparing the two groups in relation to the instrument score, a significant difference was observed between the means of the groups $\left(M_{\mathrm{PIU}}=\right.$ 61.7; $\left.S D=8.69 ; M_{\mathrm{nPIU}}=28.8 ; S D=12.3\right)$, with a large effect size $\left(F_{(1 ; 464)}=496.3 ; p<0.000 ; \eta \varrho^{2}=0.51\right)$. In Brazil, the instrument was validated by Conti et al., (2012), and was shown to have good internal consistency $(\alpha=$ $0.87)$. In the present study, the internal consistency was higher $(\alpha=0.89)$.

Depression, Anxiety and Stress Scale (DASS-21) - a shorter version of the DASS-42 scale, containing 21 items presented in a Likert-type scale ranging from 0 to 3 points. The instrument identifies symptoms of anxiety, depression, and stress from seven questions for each of the items. In the three types of mental disorders evaluated, the participants were classified into two groups: a Clinical Group (CG) and a non-Clinical Group (nCG), according to the score for each disorder. There was a significant difference between the scores of the two groups for depression $\left(F_{(1 ; 432)}=972.8 ; p<\right.$ $\left.0.000 ; \eta \varrho^{2}=0.69\right)$, anxiety $\left(F_{(1 ; 432)}=789.7 ; p<0.000 ; \eta \varrho^{2}\right.$ 
$=0.64)$ and stress $\left(F_{(1 ; 464)}=1,209 ; p<0.000 ; \eta \varrho^{2}=0.73\right)$. The instrument was adapted for use in Brazil (Patias, Machado, Bandeira \& Dell'Aglio, 2016) with a good internal consistency: depression $(\alpha=0.90)$, anxiety $(\alpha=$ 0.83 ) and stress $(\alpha=0,86)$. On this study we found the following internal consistencies: depression $(\alpha=0.87)$, anxiety $(\alpha=0.82)$, both lower, and stress $(\alpha=0.87)$.

Pediatric Quality of Life Inventory (PedsQL) - comprises 23 questions to assess the quality of life based on four dimensions: physical, emotional, social and school. This instrument has no specific classification, so that the higher the score, the better the quality of the indicator in question. The instrument was adapted and validated in Brazil by Klatchoian et al., (2008), with the following internal consistencies: physical $(\alpha=0.85)$, emotional $(\alpha=0.62)$, social $(\alpha=$ $0.66)$ and school $(\alpha=0.60)$. In this study, we observed greater internal consistencies: emotional $(\alpha=0.83)$, social $(\alpha=0.80)$ and school $(\alpha=0.69)$, except in the physical subscale $(\alpha=0.78)$.

\section{Procedures}

The method of the project was designed by researchers with different expertise, such as nutrition, psychology, pediatrics, and dentistry from two Institutions. The feasibility to implement the project was discussed with the local authority education department. The proposal for the project was well received, and a pilot was implemented, with the support of the local authority management.

The researchers assisted in data collection and the training of the curriculum coordinators, principals, assistants, and teachers about the specific procedures for the data collection. Participant data were collected on different days, and some adolescents who had not fully completed the instruments were asked to supply the missing data. Meetings and training courses were held with managers and with the parents of the students at the participating schools.

\section{Data analysis}

The continuous variables were transformed into $\mathrm{Z}$ scores to detect possible outliers that could impair the reliability of the results and responses with values below or above three standard deviations were excluded from the analyses, as in other studies (Cruz et al., 2018).

For the analysis of the categorical variables, the Chi-Square Test $(\chi 2)$ was used; for the continuous variables, One-way Analysis of Variance was used and, when ANOVA detected significance, the Scheffé a posteriori test was used to identify specific differences in analyses with more than three groups. The effect size was calculated from the Eta Square test $\left(\eta \varrho^{2}\right)$ and Cramer's $\mathrm{V}$ Test for the continuous and nominal variables, respectively (Andrade et al., 2020; Silva, Andrade, \& De Micheli, 2018). The level of significance was $5 \%$ in all analyses, and Statistica 15.0 software (Statsoft Inc ${ }^{\circledR}$ ) was used.

\section{Ethics}

This study is in accordance with Brazilian Resolution 466/2012 that regulates all researches involv-ing human being and was approved by the Ethics Committee of the Universidade Federal de São Paulo ${ }^{\circ}$ ( $\mathrm{n}^{\circ}$ 1.833.092, CAAE: 62073316.1.0000.5505) and by the Committee of Pontifícia Univer-sidade Católica de Campinas (n ${ }^{\circ}$ 2.383.838, CAAE: 75837417.1.0000.5481).

\section{Results}

The sociodemographic data showed a slightly larger number of females, the majority of students attended elementary school and were classified in socioeconomic groups $\mathrm{B}$ and $\mathrm{C}$, with an average monthly income of $\mathrm{R} \$ 7,942.58(S D=7,061.73)$, as shown in Table 1.

Regardless the internet use, $17 \%$ of students ( $n$ $=79)$ were classified as PIU, with no significant differences between males and females. The PIU adolescents had a higher frequency of students in groups A and B, with an average income of $\mathrm{R} \$ 8,545.61(S D=7,357.58)$, compared to non-problematic Internet Users (nPIU) ( $\mathrm{R} \$$ 6,954.42; $S D=7,044.84)$; but without statistically significant differences. Also, there was no difference between groups about the time spent using smartphones (Table 2).

The analysis of variance did not detect any differences between the nPIU and PIU groups regarding quality of life of all domains evaluated by PedsQL (physical, social, emotional and school), as well as in the DASS-21 subscales, as shown in Table 3. The specific results of DASS-21 indicated a high prevalence of anxiety $(28.9 \%)$, followed by stress $(24.5 \%)$ and depression $(22.7 \%)$. Among all groups, there were no statistically significant differences; but there was a slightly higher frequency of clinical depressive symptoms and a higher average gross final score in the nPIU adolescents, as well as for depression. Regarding stress symptoms, the distributions were quite similar between the two groups, without significant differences. 
Table 1.

Sociodemographic characteristics all participants $(N=466)$

\begin{tabular}{lccc}
\hline \multirow{2}{*}{ Gender } & $\mathbf{N}$ & $\mathbf{\%}$ & $\mathbf{9 5 \%} \mathbf{C I}$ \\
\cline { 2 - 4 } & & & \\
\hline Male & 219 & 47.0 & {$[0.40-0.54]$} \\
Female & 247 & 53.0 & {$[0.46-0.59]$} \\
\hline Schooling & & & \\
\hline Elementary & 304 & 65.2 & {$[0.59-0.70]$} \\
High School & 162 & 34.8 & {$[0.27-0.47]$} \\
\hline Economic class & & & \\
\hline A & 34 & 20.3 & {$[0.08-0.38]$} \\
B1/B2 & 59 & 35.3 & {$[0.23-0.49]$} \\
C1/C2 & 59 & 35.3 & {$[0.23-0.49]$} \\
D/E & 15 & 9.1 & {$[0.00-0.32]$} \\
Missing data & 299 & & \\
\hline How long have you had a smart phone? & & & \\
\hline Until 1 year & 125 & 26.8 & {$[0.19-0.35]$} \\
Between 1 and 3 years & 115 & 24.7 & {$[0.16-0.33]$} \\
Between 3 and 5 years & 92 & 19.7 & {$[0.12-0.29]$} \\
More than 5 years & 134 & 28.8 & {$[0.21-0.37]$} \\
\hline
\end{tabular}

Note: $95 \%$ CI= 95\% Confidence Interval; N = Participants. The participants' total income was R $\$ 7,942.5(S D=7,061.7)$ estimated according to the Brazilian Economic Classification Criteria.

Regardless of the self-perception of internet use, $40.1 \%(n=187)$ of the students reported that its use negatively affected their daily activities in some way. The group that felt affected showed significant differences about the other adolescents in internet dependence, with higher IAT scores; this group also presented higher levels of stress (Table 4).

\section{Discussion}

This study evaluated the relationships between emotional symptoms and quality of life, and different patterns of internet use by adolescents, with 17\% being classified in the PIU group. However, these adolescents did not present a significantly higher frequency of anxiety, stress and depression symptoms compared to other adolescents. These results are consistent with other findings in the literature, such as a Chinese study that reported that there were no differences in the frequency of depressive symptoms among PIU adolescents, but only between stress levels (Lam Peng, May, \& Jing, 2009). However, stress-related data, in particular, should be carefully analyzed, as these authors also detected other variables that may directly influence stress levels, such as alcohol consumption, family problems, and sleep time. It is possible, that they have an indirect effect on internet use, as the authors did not perform covariance analyses to control the effect of each variable related to internet use.

In the study of Ko et al (2019), the authors observed a significant relationship between depression and dependence on the internet, based on the univariate analysis. The same results were observed for anxiety symptoms, consistent with the findings of the present study. Despite these results, most studies indicate a positive correlation between PIU and depression, according to a systematic review by Carli et al., (2013). These authors evaluated 20 studies, with $75 \%$ indicating an association between PIU and depression, and almost $60 \%$ of an association with anxiety disorders. However, the authors emphasize that the great majority of the studies evaluated Asian adolescents, and the definition of PIU remains quite heterogeneous, limiting the ability to make comparisons between the studies. 
Table 2.

Sociodemographic data of problematic internet users (PIU; $n=79)$ and non-problematic internet users ( $n$ PIU; $n=387$ )

\begin{tabular}{|c|c|c|c|c|c|c|c|c|}
\hline \multirow{2}{*}{ Gender } & \multicolumn{2}{|c|}{ PIU } & \multirow[t]{2}{*}{$95 \% \mathrm{CI}$} & \multicolumn{2}{|c|}{$\mathrm{nPIU}$} & \multirow[t]{2}{*}{$95 \% \mathrm{CI}$} & \multirow[t]{2}{*}{ Test } & \multirow[t]{2}{*}{$p$} \\
\hline & $N$ & $\%$ & & $N$ & $\%$ & & & \\
\hline Male & 36 & 45.6 & {$[0.28-0.61]$} & 183 & 47.3 & [0.40-0.55] & 0.07 & 0.78 \\
\hline Female & 43 & 54.4 & {$[0.37-0.68]$} & 204 & 52.7 & {$[0.46-0.60]$} & & \\
\hline Schooling & & & & & & & 0.01 & 0.90 \\
\hline Elementary & 52 & 65.8 & {$[0.50-0.78]$} & 255 & 65.1 & {$[0.59-0.70]$} & & \\
\hline High School & 27 & 34.2 & {$[0.16-0.54]$} & 135 & 34.9 & {$[0.27-0.43]$} & & \\
\hline Economic class & & & & & & & 6.40 & 0.09 \\
\hline A & 6 & 25.0 & {$[0.04-0.77]$} & 28 & 19.6 & {$[0.06-0.36]$} & & \\
\hline $\mathrm{B} 1 / \mathrm{B} 2$ & 12 & 50.0 & {$[0.22-0.78]$} & 47 & 32.8 & {$[0.19-0.47]$} & & \\
\hline $\mathrm{C} 1 / \mathrm{C} 2$ & 4 & 16.7 & {$[0.00-0.80]$} & 55 & 38.5 & {$[0.25-0.52]$} & & \\
\hline $\mathrm{D} / \mathrm{E}$ & 2 & 8.3 & {$[0.00-0.84]$} & 13 & 9.1 & [0.01-0.33] & & \\
\hline Missing data & \multicolumn{2}{|c|}{55} & & \multicolumn{2}{|c|}{244} & & & \\
\hline $\begin{array}{l}\text { How long have you had } \\
\text { a smart phone? }\end{array}$ & & & & & & & 0.35 & 0.94 \\
\hline Until 1 year & 23 & 29.1 & {$[0.13-0.53]$} & 102 & 26.3 & {$[0.18-0.36]$} & & \\
\hline Between 1 and 3 years & 18 & 22.8 & {$[0.07-0.48]$} & 97 & 25.1 & {$[0.16-0.34]$} & & \\
\hline Between 3 and 5 years & 15 & 19.0 & {$[0.04-0.48]$} & 77 & 19.9 & {$[0.11-0.30]$} & & \\
\hline \multirow[t]{2}{*}{ More than 5 years } & 23 & 29.1 & [0.13-0.53] & 111 & 28.7 & {$[0.20-0.38]$} & & \\
\hline & $M$ & $S D$ & & $M$ & $S D$ & & & \\
\hline Age & 12.6 & 2.47 & {$[12.40-13.20]$} & 12.7 & 2.31 & [12.40-12.90] & 0.01 & 0.89 \\
\hline Income $(\mathbf{R} \$)^{\mathrm{a}}$ & $8,562.3$ & $6,920.2$ & {$[5,898-11,225]$} & $6,982.1$ & $7,030.1$ & {$[5,881-8.083]$} & 1.17 & 0.28 \\
\hline
\end{tabular}

Note: PIU = Problematic Internet Users; nPIU = non-Problematic Internet Users; 95\% CI; $p=$ significance level; $N=$ Participants, $M=$ Mean, $S D=$ Standard Deviation; ${ }^{\text {a }}$ Only 193 people filled this item.

In Brazil, some authors have observed that adolescents with PIU had a higher frequency of symptoms of depression and anxiety, but without statistical significance (Della-Méa et al., 2016). In contrast, Cruz et al., (2018), did detect a relationship between PIU and some aspects of quality of life, especially among public school students. However, in these two studies, the classification of PIU was different, with students classified as mild, moderate and severe. In the study by Machado et al., (2018), participants were classified in the same way as in the present study ( $\mathrm{PIU}=\geq 50$ points; $\mathrm{nPIU}$ $=<50$ points), and the authors detected a positive correlation with internalizing behavioural problems, such as anxiety and depression, and with externalizing problems such as aggressive behaviour.

The lack of association of PIU with emotional and behavioural variables could be associated with the sample size since it was detected some tendencies of statistical significances with the $p$-value ranging from 0.08 until 0.06 . Thus, is possible that an increase in the number of students might show a significant effect. About the perception of internet use, adolescents who reported feeling that their daily activities were affected showed higher IAT scores and higher levels of stress $(p<0.05)$. The negative effects can act as stressors and be related to a greater difficulty in dealing with everyday situations, as observed by Moromizato et al. (2017). These data are relevant because they indicate that these adolescents may be exposed for more time to ageinappropriate content, in addition to other potential internet risks.

The present study has limitations that need to be considered. Although it was based on a representative sample of students from public schools, the data was collected only in a single Brazilian city. As previously described, several psychosocial factors are involved in 
Table 3.

Quality of life, depression, anxiety, and stress in problematic internet users (PIU; $n=79)$ and non-problematic internet users ( $n$ PIU; $n$ = 387)

\begin{tabular}{|c|c|c|c|c|c|c|c|c|}
\hline & \multicolumn{2}{|c|}{ PIU } & \multirow[t]{2}{*}{$95 \% \mathrm{CI}$} & \multicolumn{2}{|c|}{$\mathrm{nPIU}$} & \multirow[t]{2}{*}{$95 \% \mathrm{CI}$} & \multirow[t]{2}{*}{ Test } & \multirow[t]{2}{*}{$p$} \\
\hline & $N$ & $\%$ & & $N$ & $\%$ & & & \\
\hline Depression & & & & & & & 1.23 & 0.26 \\
\hline Clinic & 14 & 19.5 & [0.04-0.50] & 92 & 25.7 & [0.17-0.36] & & \\
\hline Non-clinic & 58 & 80.5 & [0.68-0.90] & 267 & 74.3 & [0.68-0.79] & & \\
\hline Anxiety & & & & & & & 0.38 & 0.53 \\
\hline Clinic & 20 & 27.8 & [0.12-0.54] & 113 & 31.5 & [0.23-0.41] & & \\
\hline Non-Clinic & 52 & 72.2 & {$[0.57-0.83]$} & 246 & 68.5 & {$[0.62-0.74]$} & & \\
\hline Stress & & & & & & & 0.00 & 0.97 \\
\hline Clinic & 19 & 26.4 & [0.08-0.49] & 94 & 26.2 & [0.17-0.35] & & \\
\hline Non-Clinic & 53 & 73.6 & [0.59-0.84] & 265 & 73.8 & [0.69-0.79] & & \\
\hline Raw scores & $M$ & $S D$ & & $M$ & $S D$ & & & \\
\hline Depression & 5.88 & 8.30 & [3.74-8.03] & 6.64 & 9.42 & [5.68-7.60] & 0.40 & 0.53 \\
\hline Anxiety & 5.52 & 7.38 & [3.62-7.43] & 6.24 & 8.37 & [5.39-7.09] & 0.45 & 0.49 \\
\hline Stress & 9.13 & 10.62 & [6.73-11.5] & 9.34 & 10.34 & [8.27-10.4] & 0.02 & 0.87 \\
\hline \multicolumn{9}{|c|}{ Quality of life } \\
\hline Physical & 87.3 & 14.7 & [84.0-90.1] & 87.6 & 14.8 & [86.1-89.1] & 0.02 & 0.97 \\
\hline Emotional & 77.6 & 23.6 & [72.4-82.9] & 77.2 & 22.8 & [74.8-79.5] & 0.02 & 0.77 \\
\hline Social & 89.7 & 16.1 & [86.2-93.6] & 89.5 & 16.2 & [87.9-91.2] & 0.03 & 0.86 \\
\hline Educational & 76.9 & 18.6 & [72.7-81.1] & 76.9 & 18.4 & [75.0-78.9] & 0.04 & 0.89 \\
\hline
\end{tabular}

Note: PIU = Problematic Internet Users; nPIU = non-Problematic Internet Users; 95\% CI; $p=$ significance level; $N=$ Participants, $M=$ Mean, $S D=$ Standard Deviation

the PIU, and it is possible that these findings would be different in adolescents from other Brazilian regions. Also, the association of PIU with emotional and behavioural problems was measured using self-report questionnaires. However, it is essential to comprehend how these adolescents perceive themselves in this context and to trust that people know about themselves. Because this is a cross-sectional study, it is not possible to establish a causal relationship among variable that could provide further information about the relationships of PIU with emotional and behavioural variables. Because this is a preliminary study, we intend to publish another manuscript with longitudinal data. Besides, is that excessive use of smartphones may be a confounding factor in PIU. However, there are still no validated instruments in Brazil to assess dependence on smartphones among adolescents, limiting an in-depth evaluation of the use of smartphones and emotional problems.
In summary, our main results indicated that the prevalence of adolescents with PIU was $17 \%$, with the frequency and intensity of emotional symptoms being similar to both groups. Those who felt that their internet use had a negative effect on their daily life showed higher IAT scores and higher levels of stress. Connectivity between people is an increasingly common global phenomenon, and the study of this complex social interaction is critical to assess the impacts of technology on the psychological and social aspects of individuals.

\section{References}

Andrade, A. L. M., Kim, D. J., Caricati, V. V., Martins, G. D. G., Kirihara, I. K., Barbugli, B. C, Enumo, S. R. F., et al. (2020). Validity and reliability of the Brazilian version of the smartphone Addiction Scale-Short Version for university students and 
Table 4.

Comparison between adolescents who believed that their internet use had a negative effect on their daily lives $(n=187)$ and those who did not $(n=272)$, in regards to LAT, DASS-21 and PedsQL instruments

\begin{tabular}{|c|c|c|c|c|c|c|c|c|}
\hline \multicolumn{9}{|c|}{ Perception of internet use } \\
\hline & \multicolumn{2}{|c|}{ Negative effect } & \multirow[t]{2}{*}{$95 \% \mathrm{CI}$} & \multicolumn{2}{|c|}{ Neutral } & \multirow[t]{2}{*}{$95 \% \mathrm{CI}$} & \multirow[t]{2}{*}{ Test } & \multirow[t]{2}{*}{$p$} \\
\hline & $\mathbf{N}$ & $\%$ & & $\mathbf{N}$ & $\%$ & & & \\
\hline IAT & & & & & & & 3.23 & 0.07 \\
\hline PIU & 38 & 20.3 & {$[0.09-0.37]$} & 38 & 13.9 & {$[0.04-0.28]$} & & \\
\hline nPIU & 149 & 79.7 & {$[0.71-0.85]$} & 234 & 86.1 & {$[0.80-0.90]$} & & \\
\hline Depression & & & & & & & 0.60 & 0.43 \\
\hline Clinic & 60 & 23.4 & {$[0.13-0.36]$} & 46 & 26.7 & {$[0.14-0.41]$} & & \\
\hline Non-clinic & 196 & 76.6 & {$[0.70-0.82]$} & 126 & 73.3 & {$[0.64-0.80]$} & & \\
\hline Anxiety & & & & & & & 1.48 & 0.22 \\
\hline Clinic & 60 & 34.9 & {$[0.23-0.48]$} & 75 & 29.3 & {$[0.20-0.42]$} & & \\
\hline Non-clinic & 112 & 65.1 & {$[0.55-0.74]$} & 181 & 70.7 & {$[0.64-0.77]$} & & \\
\hline Stress & & & & & & & 1.90 & 0.16 \\
\hline Clinic & 52 & 30.3 & {$[0.34-0.51]$} & 62 & 24.2 & [0.14-0.36] & & \\
\hline \multirow[t]{2}{*}{ Non-clinic } & 120 & 69.7 & [0.60-0.78] & 194 & 75.8 & [0.69-0.81] & & \\
\hline & $\mathbf{M}$ & SD & & $\mathbf{M}$ & SD & & & \\
\hline \multicolumn{9}{|l|}{ Raw scores } \\
\hline IAT & 36.1 & 17.5 & [33.7-38.4] & 32.9 & 15.6 & [30.9-34.8] & 4.27 & $*$ \\
\hline Depression & 7.46 & 10.2 & [6.06-8.86] & 6.06 & 8.70 & [4.91-7.21] & 0.40 & 0.12 \\
\hline Anxiety & 6.97 & 8.86 & [5.74-8.21] & 5.73 & 7.78 & [4.72-6.74] & 2.34 & 0.12 \\
\hline Stress & 10.7 & 11.4 & [9.15-12.3] & 8.64 & 9.73 & [7.36-9.92] & 4.06 & $*$ \\
\hline \multicolumn{9}{|c|}{ Quality of life } \\
\hline Physical & 87.5 & 15.1 & [85.3-89.7] & 87.6 & 14.7 & [85.8-89.4] & 0.00 & 0.94 \\
\hline Emotional & 75.5 & 25.0 & [72.1-78.9] & 77.9 & 21.6 & [75.1-80.7] & 1.13 & 0.28 \\
\hline Social & 91.0 & 15.6 & [88.6-93.4] & 88.5 & 16.5 & [86.6-90.5] & 2.40 & 0.12 \\
\hline Educational & 75.8 & 18.8 & [73.1-78.6] & 77.2 & 18.1 & [74.9-79.4] & 0.57 & 0.44 \\
\hline
\end{tabular}

Note: $\mathrm{PIU}=$ Problematic Internet Users; $\mathrm{nPIU}=$ non-Problematic Internet Users; $95 \% \mathrm{CI} ; p=$ significance level; $N=$ Participants, $M=\mathrm{Mean}$, $S D=$ Standard Deviation; IAT $=$ Internet Addiction Test $* p<0.05$.

adult population. Estudos de Psicologia (Campinas), 37 , e190117. doi: 10.1590/1982-0275202037e190117

APA (American Psychiatry Association) (2013). Diagnostic and Statistical Manual of Mental Disorders (DSM-V). Porto Alegre: Artmed.

Bedendo, A., Andrade, A. L. M., \& Noto, A. R. (2018). Internet-based alcohol interventions for college students: systematic review. Pan American Journal of Public Health, 42, e54. doi: 10.26633/ RPSP.2018.54
Carli, V., Durkee, T., Wasserman, D., Hadlaczky, G., Despalins, R., Kramarz, E., ... \& Kaess, M. (2013). The association between pathological Internet use and comorbid psychopathology: a systematic review. Psychopathology, 46(1), 1-13. doi: 10.1159/000337971

Chern, K. C., \& Huang, J. H. (2018). Internet addiction: Associated with lower health-related quality of life among college students in Taiwan, and in what aspects? Computers in Human Behavior, 84, 460466. doi: 10.1016/j.chb.2018.03.011 
Brazilian Internet Management Committee (BIMC). (2019). Pesquisa sobre o uso da internet por crianças e adolescentes no Brasil : TIC kids online Brasil 2018. [Survey on internet use by children in Brazil: ICT kids online Brazil 2018] (Vol. 1). Brasilia: Comitê Gestor de Internet. Retrieved February 13, 2020, from: https://cetic.br/media/docs/ publicacoes/216370220191105/tic_kids_online_2018_livro_eletronico.pdf

Conti, M. A., Jardim, A. P., Hearst, N., Cordás, T. A., Tavares, H., \& Abreu, C. N. D. (2012). Evaluation of semantic equivalence and internal consistency of a Portuguese version of the Internet Addiction Test (IAT). Archives of Clinical Psychiatry, 39(3), 106110. doi: 10.1590/S0101-60832012000300007

Cruz, F. A. D., Scatena, A., Andrade, A. L. M., \& De Micheli, D. (2018). Evaluation of Internet addiction and the quality of life of Brazilian adolescents from public and private schools. Estudos em Psicologia (Campinas), 35(2), 193-204. doi: 10.1590/1982-02752018000200008.

Della-Méa, C. P., Biffe, E. M., \& Ferreira, V. R. T. (2016). Adolescent Internet patterns use and depressive and anxiety symptoms. Psicologia Revista, 25(2), 243-264. Retrieved from: https:// revistas.pucsp.br/index.php/psicorevista/article/ view/28988/21351

Global Web Index (GWI). (2018). Digital vs. traditional media consumption. New York. Retrieved March 11, 2020 from: https://www.globalwebindex.com/ reports/traditional-vs-digital-media-consumption

Heo, J., Oh, J., Subramanian, S. V., Kim, Y., \& Kawachi, I. (2014). Addictive Internet use among Korean adolescents: A national survey. PLoS One, 9(2), e87819. doi: 10.1371/journal.pone.0087819

Internet World Stats (IWS). (2020). World internet usage and population statistics. London. Retrieved March 11, 2020, from: https://www.internetworldstats. $\mathrm{com} / \mathrm{stats} . \mathrm{htm}$

Instituto Brasileiro de Geografia e Estatística (IBGE). (2018). Pesquisa Nacional por Amostra de Domicílios [National Sample Household Survey]. Rio de Janeiro: IBGE. Retrieved March 11, 2020 from: https://ww2.ibge.gov.br/home/estatistica/indicadores/trabalhoerendimento/pnad_continua/ default.shtm
Kaess, M., Parzer, P., Brunner, R., Koenig, J., Durkee, T., Carli, V., Camilla Wasserman, C, et al. (2016). Pathological Internet use is on the rise among European adolescents. Journal of Adolescent Health, 59(2), 236239. doi: 10.1016/j.jadohealth.2016.04.009

Klatchoian, D. A., Len, C. A., Terreri, M. T. R., Silva, M., Itamoto, C., Ciconelli, R. M., Varni, J. W., et al. (2008). Quality of life of children and adolescents from São Paulo: Reliability and validity of the Brazilian version of the Pediatric Quality of Life InventoryTM version 4.0 Generic Core Scales. Jornal de Pediatria, 84(4), 308-315. doi: 10.1590/ S0021-75572008000400005

Ko, C. H., Yen, J. Y., Chen, C. S., Yeh, Y. C., \& Yen, C. F. (2009). Predictive values of psychiatric symptoms for Internet addiction in adolescents: A 2-year prospective study. Archives of Pediatrics \& Adolescent Medicine, 163(10), 937-943. doi: 10.1001/ archpediatrics.2009.159

Kuss, D. J., Kanjo, E., Crook-Rumsey, M., Kibowski, F., Wang, G. Y., \& Sumich, A. (2018). Problematic mobile phone use and smartphone addiction across generations: the roles of psychopathological symptoms and smartphone use. Journal of Technology in Behavioral Science, 3(3), 141-149. doi: 10.1007/ s41347-017-0041-3

Lai, C. M., Mak, K. K., Watanabe, H., Jeong, J., Kim, D., Bahar, Ramos, M., et al. (2015). The mediating role of Internet addiction in depression, social anxiety, and psychosocial well-being among adolescents in six Asian countries: a structural equation modelling approach. Public Health, 129(9), 1224-1236. doi: 10.1016/j.puhe.2015.07.031

Lam, L. T., Peng, Z. W., Mai, J. C., \& Jing, J. (2009). Factors associated with Internet addiction among adolescents. Cyberpsychology \& Behavior, 12(5), 551 555. doi: $10.1089=$ cpb.2009.0036

Machado, M. D. R., Bruck, I., Antoniuk, S. A., Cat, M. N. L., Soares, M. C., \& Silva, A. F. D. (2018). Internet addiction and its correlation with behavioral problems and functional impairments-A crosssectional study. Jornal Brasileiro de Psiquiatria, 67(1), 34-38. doi: 10.1590/0047-2085000000181

Mak, K. K., Lai, C. M., Watanabe, H., Kim, D. I., Bahar, N., Ramos, M., Young, K.S, Chen, S. H., et al. (2014). Epidemiology of Internet behaviors and addiction among adolescents in six Asian countries. 
Cyberpsychology, Behavior, and Social Networking, 17(11), 720-728. doi: 10.1089/cyber.2014.0139

Moromizato, M. S., Ferreira, D. B. B., Souza, L. S. M. D., Leite, R. F., Macedo, F. N., \& Pimentel, D. (2017). The use of the Internet and Social networks and the relationship with symptoms of anxiety and depression among medical students. Revista Brasileira de Educação Médica, 41(4), 497-504. doi: 10.1590/1981-52712015v41n4rb20160118

Organization for Economic Co-operation and Development (OECD). (2017). PIS A (Programme for International Student Assessment) 2015 results. Paris: OECD. Retrieved March 11, 2020 from: http:// gpseducation.oecd.org/CountryProfile?primaryC ountry $=$ BRA\&treshold $=10 \&$ topic $=$ PI

Terres-Trindade, M., \& Pereira Mosmann, C. (2016). Family conflict and parenting practices as predictors of Internet addiction. Psico-USF, 21(3), 623-633. doi: 10.1590/1413-82712016210315

Patias, N. D., Machado, W. D. L., Bandeira, D. R., \& Dell'Aglio, D. D. (2016). Depression Anxiety and Stress Scale (DASS-21)-Short Form: Adaptation and validation for Brazilian adolescents. Psico-USF, 21(3),459-469. doi:10.1590/1413-82712016210302

Silva, M. A. A., Andrade, A. L. M., \& De Micheli, D. (2018). Evaluation of the Implementation of Brief Interventions to Substance Abuse in a Socieducative Context. Revista Psicologia em Pesquisa, 12(1), 1-10. doi: 10.24879/2018001200100125

Tateno, M., Teo, A. R., Shiraishi, M., Tayama, M., Kawanishi, C., \& Kato, T. A. (2018). The prevalence rate of Internet addiction among Japanese college students: Two cross-sectional studies and reconsideration of cut-off points of young's Internet addiction test in Japan. Psychiatry and Clinical Neurosciences, 72, 723-730. doi: 10.1111/pcn.12686

Yamauchi, L. M., Andrade, A. L. M., Pinheiro, B. D. O., Enumo, S. R. F., \& De Micheli, D. (2019). Social representation regarding the use of alcoholic beverages by adolescents. Estudos de Psicologia (Campinas), 36, e180098. doi: 10.1590/1982-0275201936e180098

Recebido em: 20/04/2019

Reformulado em: 19/03/2020

Aprovado em: 27/03/2020

About the authors:

André Luiz Monezi Andrade is a professor at the Department of Psychology, PUC-Campinas. He holds an MSc and Ph.D. degrees from the Department of Psychobiology, UNIFESP, where he also conducted post-doctoral studies, always focusing on addiction's neurobiology in adolescence. His main research interests are internet and substance abuse, psychopathology, and preventive programs in adolescents' behavioral addiction.

ORCID: https://orcid.org/0000-0003-0111-8935

E-mail: andre.andrade@puc-campinas.edu.br

Sônia Regina Fiorim Enumo - Degree in Psychology by the PUC-Campinas, Master in Special Education by the Federal University of São Carlos. She is also a Ph.D. in Experimental Psychology from the University of São Paulo, with a post-doctorate in dynamic assessment of children with visual impairment at the UNICAMP. She is a professor at the Graduate Program in Psychology and Health Sciences at PUC-Campinas.

ORCID: https://orcid.org/0000-0001-9038-6151

E-mail: sonia.enumo@gmail.com

Maria Aparecida Zanetti Passos - Graduated from the UFOP, Specialization, MSc and Ph.D. in Pediatrics and Sciences Applied to Pediatrics at the UNIFESP and post-doctoral student in the Education and Health in Childhood and Adolescence Program at UNIFESP. Current lines of research include Epidemiological and Clinical Studies; Growth and Development; Micronutrient deficiency; Anemia; Malnutrition; Childhood and Adolescent Obesity.

ORCID: https://orcid.org/0000-0003-4626-0871

E-mail: cidazpassos94@yahoo.com.br 
Eliana Pereira Vellozo has a Ph.D. in Pediatrics from UNIFESP. Post-doctorate in Pediatrics by UNIFESP. She is currently a researcher and supervisor at the Adolescent Medicine Sector Outpatient Clinic of the Department of Pediatrics/UNIFESP. Technical Advisor at the Municipality of Santana de Parnaíba and Coordinator of the Education and Health Sector: Epidemiological Investigation and School Surveillance. Operates in a Pediatric Nutritional Support.

ORCID: https://orcid.org/0000-0002-8928-0699

E-mail: elianavellozo.educ@gmail.com

Teresa Helena Schoen - Psychologist and Pedagogue, Specialist in Adolescence and Psychopedagogy, Ph.D. in Sciences by Unifesp. Crowded at the Centro de Atendimento e Apoio ao Adolescente - Unifesp, being responsible for psychological and psycho-pedagogical assistance. Facilitator of the Friends Method and Master Facilitator of the ACT Program, from APA.

ORCID: https://orcid.org/0000-0002-4743-8435

E-mail:rpetrass@uol.com.br

Marco Antônio Kulik - Bachelor's at Faculdade de Odontologia de São Paulo from Universidade de São Paulo. MsC on odontology in Universidade de São Paulo.

ORCID: https://orcid.org/0000-0003-4066-3442

E-mail:profilatika@gmail.com

Sheila Rejane Niskier - Pediatrician, a specialist in adolescents from the Brazilian Society of Pediatrics, masters in pediatrics from the UNIFESP, works in an outpatient service of Medicine of adolescents in UNIFESP, worked in a pediatric ward in the municipality of São Paulo, nowadays retired for that service.

ORCID: https://orcid.org/0000-0001-5017-4680

E-mail: sheilaniskier@uol.com.br

Maria Sylvia de Souza Vitalle - Graduate at Medicine from Universidade de Mogi das Cruzes (1982), MSc on Pediatrics from UNIFESP (1994) and Ph.D. at Medicine from UNIFESP (2001). Professor and Head at Adolescent Medicine, UNIFESP, and Permanent Professor at Pos Graduate Program Educa-tion and Health in Childhood and Adolescence, UNIFESP. Research Group Leader "Comprehensive and Interdisciplinary Care for Adolescents", registered in the CNPq Research Directory. She has experience in Medicine, acting on the following subjects: adolescence, adolescente behavior, ado-lescente health, assessment, nutritional evaluation, growing.

ORCID: https://orcid.org/0000-0001-9405-4250

E-mail: sylviavitalle@gmail.com

Contact:

Eliana P. Vellozo, Ph.D.

Adolescent Medicine Sector - CAAA / Adolescent Service and Support Center. Department of Pediatrics

Universidade Federal de São Paulo

Rua Botucatu, 715, Vila Clementino

São Paulo-SP, Brasil

CEP: 04023-062

Tel +55 (11) 5576-4848 